\title{
Fair Plan 5: A Critical Appraisal of Five Congressional Bills to Reduce US $\mathrm{CO}_{2}$ Emissions
}

\author{
Michael E. Schlesinger, Michael Ring, Daniela Lindner, Emily Cross, \\ Victoria Prince \\ Climate Research Group, Department of Atmospheric Sciences, University of Illinois, Urbana, USA \\ Email: schlesin@illinois.edu
}

Received 26 September 2014; revised 30 October 2014; accepted 19 November 2014

Academic Editor: Mohammad Valipour, University of Tehran, Iran

Copyright (C) 2014 by authors and Scientific Research Publishing Inc.

This work is licensed under the Creative Commons Attribution International License (CC BY).

http://creativecommons.org/licenses/by/4.0/

(c) (i) Open Access

\section{Abstract}

The most recent US Congressional climate bill, H.R.5271 in 2014, proposes to reduce US emissions of carbon dioxide relative to their 2005 value by $80 \%$ in 2050 . This bill does not provide a rationale for this rapid phase down of $\mathrm{CO}_{2}$ emissions. In 2012, we crafted a Fair Plan to Safeguard Earth's Climate such that: 1 ) The cumulative trade-adjusted $\mathrm{CO}_{2}$ emissions by the developing countries equal the cumulative trade-adjusted $\mathrm{CO}_{2}$ emissions by the developed countries; 2) The maximum global warming above preindustrial temperature does not exceed the $2^{\circ} \mathrm{C}\left(3.6^{\circ} \mathrm{F}\right)$ chosen by the United Nations Framework Convention on Climate Change "to prevent dangerous anthropogenic interference with the climate system"; and 3) The phase out of $\mathrm{CO}_{2}$ emissions begins as late as possible in the $21^{\text {st }}$ century and proceeds at the slowest possible pace, consistent with objectives 1 and 2. The Fair Plan begins in 2020 and reduces the world's emissions to zero in 2100 . In the Fair Plan the emissions of the developed countries, including the United States, reach $80 \%$ below their 2005 values in 2094, that is, 44 years later than proposed by H.R.5271. While it is imperative that humanity begins to wean itself from fossil fuels no later than 2020, the transition from fossil to non-fossil energy need not be completed before 2100 if all countries follow their Fair Plan trajectories.

\section{Keywords}

Climate Change, Global Warming, Greenhouse-Gas Emissions, Mitigation 


\section{Introduction}

As shown in Table 1, the Congress of the United States has considered several bills to reduce the US annual emission of greenhouse gases, the most important of which is carbon dioxide $\left(\mathrm{CO}_{2}\right)$. The annual US equivalent $\mathrm{CO}_{2}$ emissions proposed in the 2003, 2005, 2007, 2009 and 2014 US Congressional bills [1]-[5] are shown in Figure 1, together with the historical annual US CO $\mathrm{CO}_{2}$ emissions from 1900 through 2012.

In these Congressional bills the emissions are given in "carbon dioxide equivalents" which was first defined in the 2005 bill as: "For each greenhouse gas, the amount of each such greenhouse gas that makes the same contribution to global warming as one metric ton of carbon dioxide, as determined by the administrator (of the Environmental Protection Agency)” [2].

Because the Congressional bills leave it to the future to define "carbon dioxide equivalents", we will treat the emission of "carbon dioxide equivalents" as the emission of $\mathrm{CO}_{2}$ alone. Since the emission of equivalent $\mathrm{CO}_{2}$, however defined, is not less than the emission of $\mathrm{CO}_{2}$ alone, the treatment of equivalent $\mathrm{CO}_{2}$ as $\mathrm{CO}_{2}$ alone will not affect our conclusion about the US Congressional bills.

In the 2003 bill the annual US $\mathrm{CO}_{2}$ emission was fixed at $5.8960 \mathrm{Gt}$ (billion metric tonnes) in 2010. It was then reduced stepwise to $5.1230 \mathrm{Gt} \mathrm{CO}_{2}$ in 2016. By comparison, the US Carbon Dioxide Information Analysis

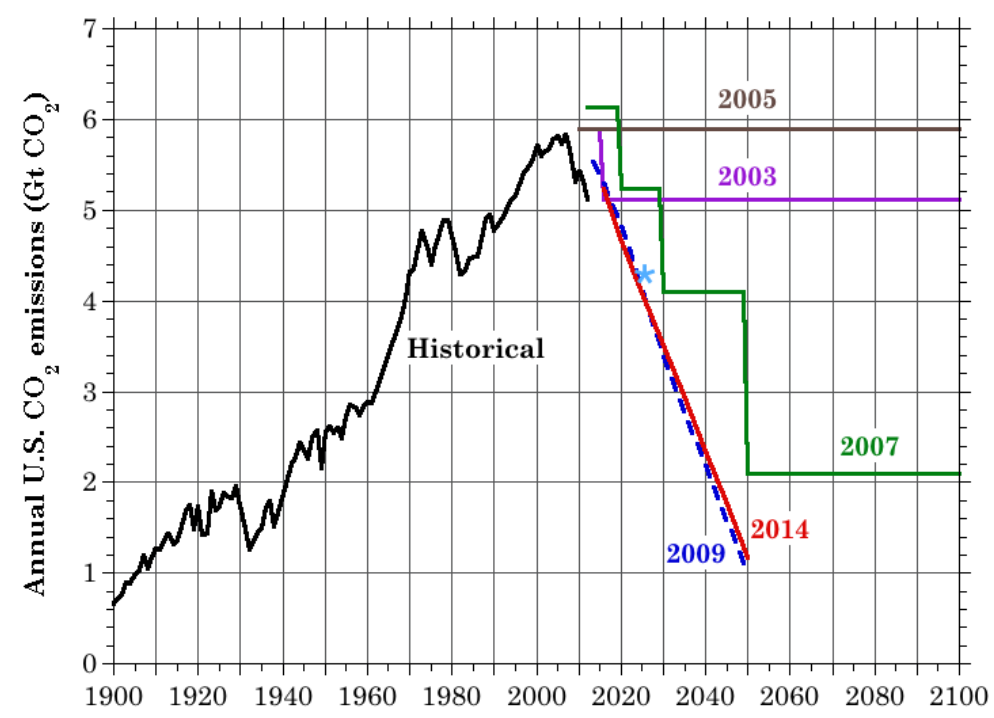

Figure 1. Historical annual US $\mathrm{CO}_{2}$ emissions (black line) and proposed future US annual (equivalent) $\mathrm{CO}_{2}$ emissions proposed in the five Congressional climate bills (purple, brown, green, blue and red lines) of Table 1. Historical emissions through 2010 are from [6] and the estimated 2011 \& 2012 emissions are from [17]. The emissions reduction cited in the White House press release of 11 November 2014 about the US-China Joint Announcement on Climate Change and Clean Energy Cooperation [18] is shown by the cyan asterisk.

Table 1. Selected US Congressional bills that propose reduction in annual US emissions of greenhouse gases.

\begin{tabular}{|c|c|c|c|c|c|}
\hline Year & Congress/Session & Bill Number & Title & Sponsor & Status \\
\hline 2003 & 108th/1st & S.139 & $\begin{array}{l}\text { Climate Stewardship Act of } \\
\qquad 2003[1]\end{array}$ & $\begin{array}{r}\text { Sen. J. Lieberman } \\
\text { (D, Connecticut) }\end{array}$ & $\begin{array}{l}\text { Referred to Senate Committee on Environment } \\
\text { and Public Works on 10/30/2003 }\end{array}$ \\
\hline 2005 & 109th/1st & S.1151 & $\begin{array}{l}\text { Climate Stewardship and } \\
\text { Innovation Act of } 2005 \text { [2] }\end{array}$ & $\begin{array}{l}\text { Sen. J. McCain } \\
\text { (R, Arizona) }\end{array}$ & $\begin{array}{l}\text { Referred to the Committee on Environment and } \\
\text { Public Works on 5/26/2005 }\end{array}$ \\
\hline 2007 & 110 th/1st & S.280 & $\begin{array}{l}\text { Climate Stewardship and } \\
\text { Innovation Act of } 2007 \text { [3] }\end{array}$ & $\begin{array}{l}\text { Sen. J. Lieberman } \\
\text { (I, Connecticut) }\end{array}$ & $\begin{array}{l}\text { Sent to Committee on Environment and Public } \\
\text { Works on } 7 / 24 / 2007\end{array}$ \\
\hline 2009 & 111th/1st & H.R.2454 & $\begin{array}{l}\text { American Clean Energy and } \\
\text { Security Act of } 2009[4]\end{array}$ & $\begin{array}{l}\text { Rep. H. Waxman } \\
\text { (D, California) }\end{array}$ & $\begin{array}{c}\text { Passed House on 6/26/2009; Placed on Senate } \\
\text { Legislative Calendar on } 7 / 7 / 2009\end{array}$ \\
\hline 2014 & 113th/2nd & H.R.5271 & $\begin{array}{l}\text { Healthy Climate and Family } \\
\text { Security Act of } 2014 \text { [5] }\end{array}$ & $\begin{array}{l}\text { Rep. C. Van Hollen } \\
\text { (D, Maryland) }\end{array}$ & $\begin{array}{l}\text { Referred to Committee on Energy \& Commerce } \\
\text { \& Committee on Ways \& Means on 7/13/2014 }\end{array}$ \\
\hline
\end{tabular}


Center reports 2005 US CO$_{2}$ emissions of 5.8259 Gt [6]. Thus the 2003 bill would have reduced US total emissions to $88 \%$ of this value.

In the 2005 bill the annual US $\mathrm{CO}_{2}$ emission was fixed at $5.8960 \mathrm{Gt}$ in 2010 , that is, at $101 \%$ of the now-historical $2005 \mathrm{CO}_{2}$ emission. In the 2007 bill three stepwise decreases in the annual $\mathrm{CO}_{2}$ emission were proposed to $2.0960 \mathrm{Gt}$ in 2050 , that is, to $36 \%$ of the 2005 emission.

In both the 2009 and 2014 bills essentially the same linear-in-time decreases in annual US $\mathrm{CO}_{2}$ emission were proposed, the former beginning in 2012 at $97 \%$ of the 2005 emission and reaching $17 \%$ thereof in 2050, and the latter beginning in 2016 at $90 \%$ of the 2005 emission and reaching $20 \%$ thereof in 2050 .

No explanation is provided in any of these US Congressional bills for their emission-reduction schedule, shown in Figure 1.

In contrast, we have crafted a Fair Plan to Safeguard Earth's Climate [7] based on three objectives. These objectives are described in Section 3. In Section 4 we contrast the 2014 US Congressional bill with the Fair Plan. As we shall see, the 2014 US Congressional bill reduces US $\mathrm{CO}_{2}$ emissions at a rate that exceeds the rate needed to solve the problem of human-caused global warming.

\section{On the Origin of the $80 \%$ Reduction by 2050 Notion}

We have endeavored to learn the origin of the " $80 / 50$ " notion to reduce emissions by $80 \%$ relative to a reference year by 2050. It appears that a "causality chain" is from the Intergovernmental Panel on Climate Change (IPCC) Assessment Report 4 (AR4) to the European Council to the $\mathrm{EUCO}_{2} 80 / 50$ project. According to the latter:

“The European Commission's ambitious objective manifests the intention to reduce the global $\mathrm{CO}_{2}$ emissions by $50 \%$ compared to 1990 , by the year 2050 . Only this can ensure that the average global warming does not exceed 2 degrees centigrade. This requires the industrialised countries to reduce their emissions by $80 \%$, in order to compensate for the lower mitigation capacities of the developing countries, due to the backlog demands of their national economies.” [8]

This notion appears on Page 7 of the Presidency Conclusions—Brussels, 29/30 October 2009 of the European Council:

"The European Council calls upon all Parties to embrace the $2^{\circ} \mathrm{C}$ objective and to agree to global emission reductions of at least $50 \%$, and aggregate developed country emission reductions of at least $80 \%-95 \%$, as part of such global emission reductions, by 2050 compared to 1990 levels; such objectives should provide both the aspiration and the yardstick to establish mid-term goals, subject to regular scientific review. It supports an EU objective, in the context of necessary reductions according to the IPCC by developed countries as a group, to reduce emissions by $80 \%$ - 95\% by 2050 compared to 1990 levels.” [9]

This notion apparently arose from Table SPM.5 "Characteristics of post-TAR stabilization scenarios" (Category A.1) of the Summary for Policymakers of the Fourth Assessment Report (AR4) of Working Group 3 (WG3) of the Intergovernmental Panel on Climate Change (IPCC) [10], and Table 3.10 (Class I) and Figure 3.38 of Chapter 3 of AR4 of IPCC WG3 [11]. These tables show that to limit global warming to $2.0^{\circ} \mathrm{C}-2.4^{\circ} \mathrm{C}$ requires emissions reductions below 2000 values of $85 \%-50 \%$ in 2050 .

These $85 \%$ - 50\% emissions reductions are what are required for scenarios that stabilize the $\mathrm{CO}_{2}$ concentration at 350 to 400 parts per million by volume (ppmv), and the equivalent $\mathrm{CO}_{2}$ concentration at 445 to $490 \mathrm{ppmv}$, respectively [10] [11]. Stabilizing the (equivalent) $\mathrm{CO}_{2}$ concentration allows the (equivalent) $\mathrm{CO}_{2}$ emissions to be nonzero in perpetuity, as long as they equal the natural (equivalent) $\mathrm{CO}_{2}$ sinks plus any human-caused (equivalent) $\mathrm{CO}_{2}$ sinks, such as carbon capture and sequestration.

In the following section we present our Fair Plan to Safeguard Earth's Climate. The Fair Plan achieves the same objective of preventing the global warming from exceeding $2^{\circ} \mathrm{C}\left(3.6^{\circ} \mathrm{F}\right)$, not by stabilizing the concentration of (equivalent) $\mathrm{CO}_{2}$, but by reducing the emissions of greenhouse gases to zero. Doing this allows for a much more gradual reduction in (equivalent) $\mathrm{CO}_{2}$ emissions than does stabilizing the (equivalent) $\mathrm{CO}_{2}$ concentration.

\section{Fair Plan to Safeguard Earth's Climate}

The Fair Plan to Safeguard Earth's Climate [7] was crafted based on three objectives:

Objective 1: The cumulative trade-adjusted $\mathrm{CO}_{2}$ emissions by the developing countries equal the cumulative 
trade-adjusted $\mathrm{CO}_{2}$ emissions by the developed countries. Trade-adjusted emissions mean the emissions incurred by Country A to export goods and/or services to Country B are debited to Country B, not Country A.

Objective 2: The maximum global warming above preindustrial temperature does not exceed the $2^{\circ} \mathrm{C}\left(3.6^{\circ} \mathrm{F}\right)$ chosen by the United Nations Framework Convention on Climate Change (UNFCCC) "to prevent dangerous anthropogenic interference with the climate system" [12].

Objective 3: The phase out of $\mathrm{CO}_{2}$ emissions are begun as late as possible in the $21^{\text {st }}$ century and proceeds at the slowest possible pace, consistent with Objectives 1 and 2.

To craft the Fair Plan to Safeguard Earth's Climate that satisfies these three Objectives, we used our Simple (engineering-type) Climate Model [13] to calculate the change in global-average near-surface air temperature from 1765 through year 3000 for historical emissions and two scenarios of future emissions of $\mathrm{CO}_{2}: 1$ ) a "Business-as-Usual” Reference scenario-the Representative Concentration Pathway 8.5 scenario (RCP-8.5); and 2) a Mitigation scenario-the Fair Plan scenario. For the emissions of the other greenhouse gases we took their curves from RCP-8.5 and applied the same intensities thereto for the developed and developing countries as we did for $\mathrm{CO}_{2}$. Further details of these calculations are described in our four antecedent papers [7] [14]-[17].

The global annual $\mathrm{CO}_{2}$ emissions for the Reference scenario and the Fair Plan are shown in Figure 2, together with the historical global annual $\mathrm{CO}_{2}$ emissions. The annual emissions for the Reference scenario increase throughout the $21^{\text {st }}$ century, reaching a value of almost $106 \mathrm{Gt} \mathrm{CO}_{2}$ by 2100. (Note that, in our earlier Fair Plan papers we reported these annual emissions in Gt C.) The global annual $\mathrm{CO}_{2}$ emissions for the Fair Plan begin to deviate from those of the Reference scenario beginning in 2020. Note however that these Fair Plan global annual

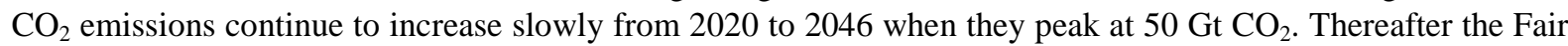
Plan global annual $\mathrm{CO}_{2}$ emissions decrease to zero in 2100. The annual $\mathrm{CO}_{2}$ emissions of the developed and developing countries are presented in Section 3.

The $\mathrm{CO}_{2}$ concentrations for the Reference scenario and the Fair Plan are shown in Figure 3, together with the historical $\mathrm{CO}_{2}$ concentrations. The concentrations for the Reference scenario increase throughout the $21^{\text {st }}$ century, reaching a value of almost 936 parts per million by volume (ppmv) by 2100 which is 3.4 times the pre-industrial concentration of 277 ppmv. In contrast, the $\mathrm{CO}_{2}$ concentrations for the Fair Plan increase to only 612 ppmv by 2088 and thereafter decrease to 604 ppmv in 2100, a difference then of 332 ppmv from the concentration for the Reference scenario.

The change in global-mean near-surface air temperature from its preindustrial (1765) value is shown in Figure 4 for the Reference scenario and Fair Plan, together with the historical values. For the Reference scenario the temperature change increases throughout the $21^{\text {st }}$ century, reaching $3.4^{\circ} \mathrm{C}\left(6.1^{\circ} \mathrm{F}\right)$ in 2100 , a global warming which exceeds the UNFCCC limit by $1.4^{\circ} \mathrm{C}\left(2.5^{\circ} \mathrm{F}\right)$. In contrast, the temperature change for the Fair Plan in-

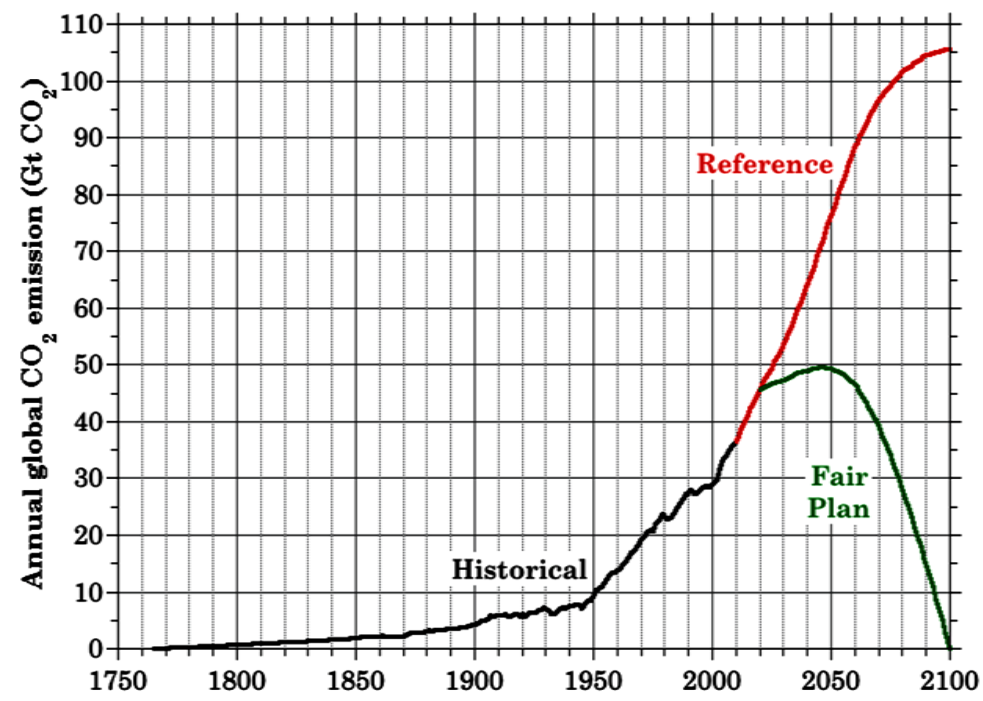

Figure 2. Historical (black line) and future annual global $\mathrm{CO}_{2}$ emissions, the latter for the Reference (RCP-8.5; red line) and Fair Plan [7] (green line) scenarios. 


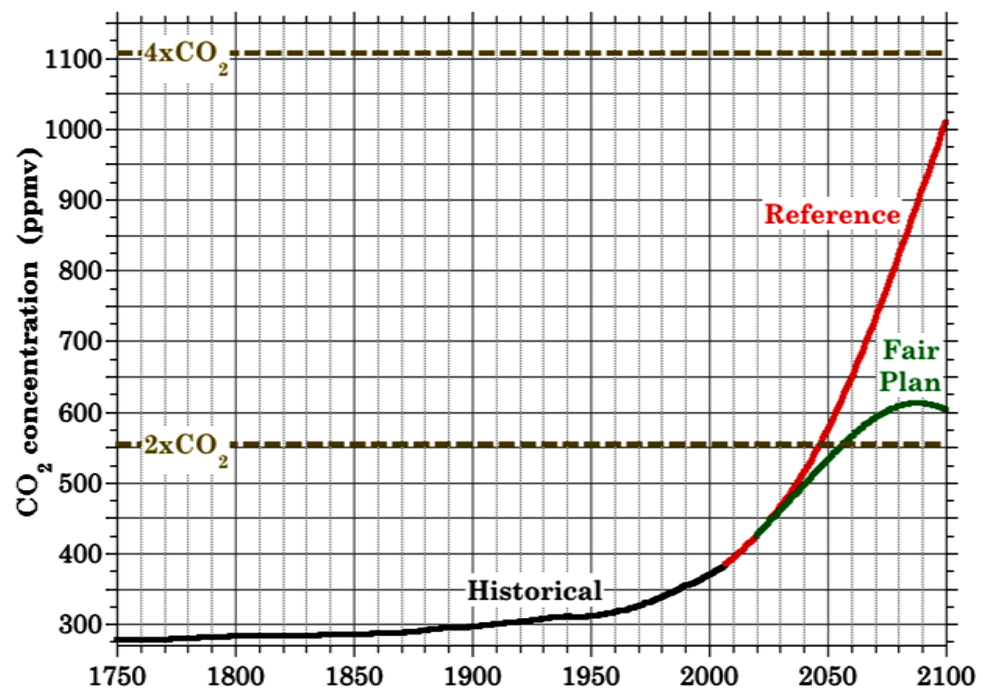

Figure 3. Historical (black line) and future annual global $\mathrm{CO}_{2}$ concentrations, the latter for the Reference (RCP-8.5; red line) and Fair Plan [7] (green line) scenarios. Twice and quadruple the pre-industrial $\mathrm{CO}_{2}$ concentration are shown by the brown dashed lines.

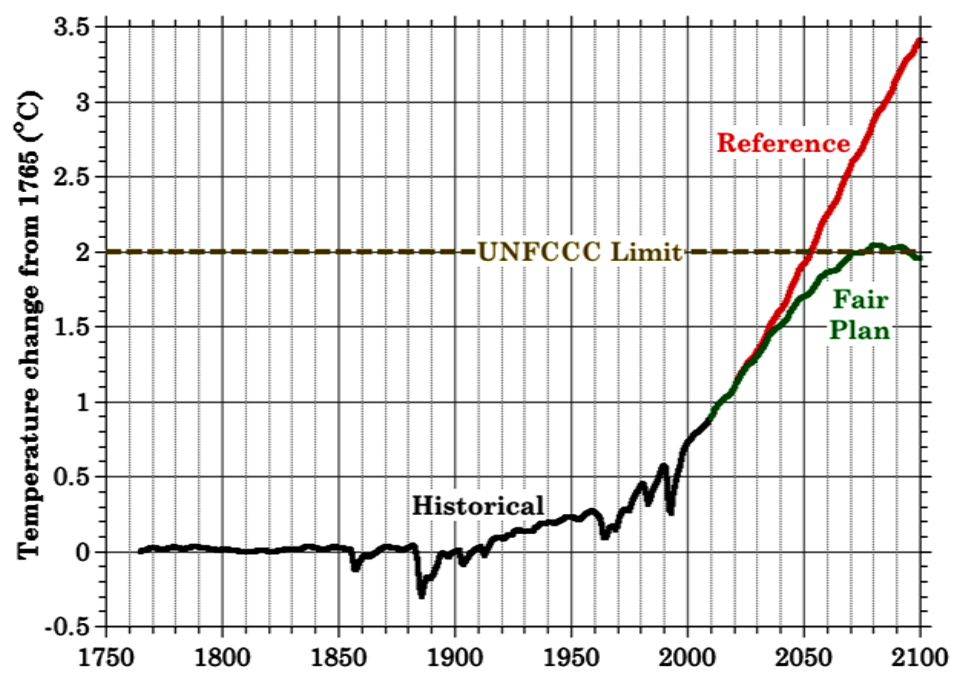

Figure 4. Historical (black line) and future annual global-average near-surface temperature changes from 1756, the latter for the Reference (RCP-8.5; red line) and Fair Plan [7] (green line) scenarios. The $2^{\circ} \mathrm{C}\left(3.6^{\circ} \mathrm{F}\right) \mathrm{UNFCCC}$ limit "to prevent dangerous anthropogenic interference with the climate system" [12] is shown by the brown dashed line.

creases to the $2^{\circ} \mathrm{C}\left(3.6^{\circ} \mathrm{F}\right) \mathrm{UNFCCC}$ limit by 2077 , stays just above (by no more than $0.04^{\circ} \mathrm{C}$ ) until 2096, and then begins to decrease. As shown by our second Fair Plan paper [7], this temperature decrease continues throughout the third millennium to $0.9^{\circ} \mathrm{C}\left(1.6^{\circ} \mathrm{F}\right)$ in year 3000 , when the global warming of the reference scenario is $5.3^{\circ} \mathrm{C}\left(9.5^{\circ} \mathrm{F}\right)$.

\section{Comparison of the 2014 Bill and the Fair Plan}

The annual $\mathrm{CO}_{2}$ emissions for the developed and developing countries are shown in Figure 5, together with those proposed for the United States by the 2014 US Congressional bill (Table 1), in terms of the percentage change from the $2005 \mathrm{CO}_{2}$ emissions for the developed countries, developing countries and the United States. 


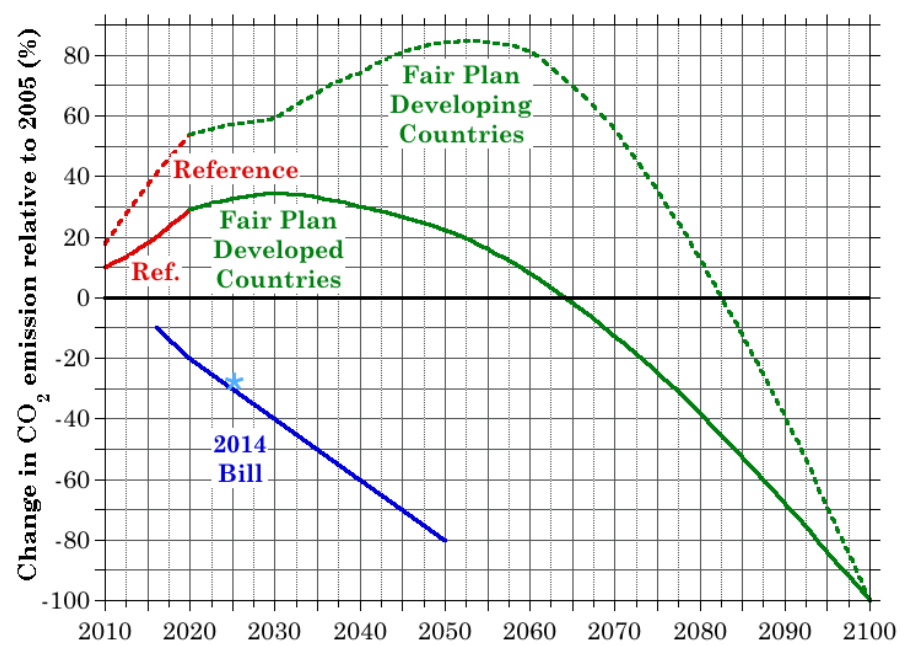

Figure 5. Percentage change in annual $\mathrm{CO}_{2}$ emissions for the Reference (RCP8.5; red lines) and Fair Plan (green lines) scenarios for the developed and developing countries [7], and for the US as proposed by the 2014 Congressional bill [5] (blue line), relative to their respective $2005 \mathrm{CO}_{2}$ emissions. The emissions reduction cited in the White House press release of 11 November 2014 about the US-China Joint Announcement on Climate Change and Clean Energy Cooperation [18] is shown by the cyan asterisk.

The $\mathrm{CO}_{2}$ emissions for the developed and developing countries were calculated as the product of the Reference $\mathrm{CO}_{2}$ emission scenario and an annual $\mathrm{CO}_{2}$ intensity, which is unity in the starting year YS of the phaseout and decreases to zero in ending year YE of the phaseout, linearly in time for the developed countries and cubically in time for the developing countries. In our first Fair Plan paper [14], YE and the duration of the phaseout, $\mathrm{D}=\mathrm{YE}-\mathrm{YS}$, were prescribed to be 2015 and 50 years, respectively. In our second Fair Plan paper [7], we examined YE from 2015 to 2025 in 5-year increments, and D from 50 to 100 years in 10-year increments. We found that Objective 2 could not be attained if YS and D exceeded 2020 and 80 years, respectively. Thus in our third and fourth Fair Plan papers [15] [16] and here, YS = 2020 and YE $=2100$. These starting and ending years of the phaseout uniquely define the coefficients of the linear-in-time intensity curve for the developed countries. The starting and ending years, and the requirement that the cumulative $\mathrm{CO}_{2}$ emissions of the developing countries equal the cumulative $\mathrm{CO}_{2}$ emissions of the developed countries, uniquely determine the coefficients of the cubic-in-time intensity curve for the developing countries [7]. The resulting annual $\mathrm{CO}_{2}$ emissions trajectories are shown in Figure 5 in terms of the percentage change from the $2005 \mathrm{CO}_{2}$ emissions for the developed and developing countries, respectively, this for comparison with the percentage changes specified in the 2014 US Congressional bill for the United States.

Figure 5 shows that in the Fair Plan the annual $\mathrm{CO}_{2}$ emissions of the developed countries, including the US, and developing countries increase slightly until 2030 and 2053, respectively. In the Fair Plan the annual $\mathrm{CO}_{2}$ emissions of the US and all other developed countries in 2050 are 22\% above their 2005 value. The developed countries $\mathrm{CO}_{2}$ emissions reach 80\% below their 2005 values in 2094, 44 years later than proposed in the 2014 US Congressional bill for the United States.

\section{Conclusions}

The most recent US Congressional climate bill, H.R.5271 in 2014, proposes to reduce US annual equivalent

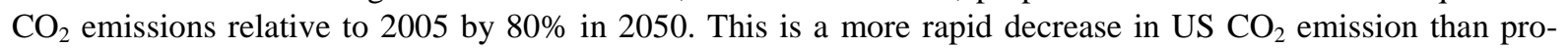
posed in the three antecedent congressional bills: S.139, S.1151 and S.280, and is 3\% less than that proposed by H.R.2454 (Table 1 and Figure 1). No justification is given by any of these bills for their proposed time schedule for the reduction in US annual equivalent $\mathrm{CO}_{2}$ emissions.

The Fair Plan to Safeguard Earth's Climate that we crafted in 2012 eliminates the worldwide emission of $\mathrm{CO}_{2}$ from 2020 to 2100, allows the cumulative $\mathrm{CO}_{2}$ emissions by the developing countries to equal the cumulative 
$\mathrm{CO}_{2}$ emissions by the developed countries, and keeps the rise in the global-mean near-surface temperature within $0.04^{\circ} \mathrm{C}\left(0.07^{\circ} \mathrm{F}\right)$ above the $2^{\circ} \mathrm{C}\left(3.6^{\circ} \mathrm{F}\right)$ limit adopted by the UN Framework Convention on Climate Change "to prevent dangerous human intervention in the climate system". In the Fair Plan the $\mathrm{CO}_{2}$ emissions of the developed countries, including the US, increase slightly until 2030, while the $\mathrm{CO}_{2}$ emissions of the developing countries increase until 2053. In the Fair Plan the $\mathrm{CO}_{2}$ emissions of the US and all other developed countries in 2050 are $22 \%$ above their 2005 value. These developed countries $\mathrm{CO}_{2}$ emissions reach $80 \%$ below their 2005 values only in 2094, 44 years later than proposed in the 2009 and 2014 congressional bills.

While it is imperative that humanity begins to wean itself from fossil fuels no later than 2020, the transition from fossil-fuel energy to non-fossil-fuel energy need not be completed before 2100 if all countries follow their Fair Plan trajectories. However, if not all countries do so, then the $2^{\circ} \mathrm{C}$ goal will be exceeded. So, while the trajectory under H.R.5271 is more rapid than necessary for the United States, it is imperative that the United States exerts leadership to ensure that other countries participate in the Fair Plan.

\section{References}

[1] Lieberman, J. (2003) Climate Stewardship Act of 2003, in S.139. US Senate, Washington DC.

[2] McCain, J. (2005) Climate Stewardship and Innovation Act of 2005 in S.1151. US Senate, Washington DC.

[3] Lieberman, J. (2007) Climate Stewardship and Innovation Act of 2007, in S.280. US Senate, Washington DC.

[4] Waxman, H. (2009) American Clean Energy and Security Act of 2009, in H.R.2454. US House of Representatives, Washington DC.

[5] Van Hollen Jr., C. (2014) Healthy Climate and Family Security Act of 2014, in H.R.5271. US House of Representatives, Washington DC.

[6] Boden, T., Marland, G. and Andres, B. (2013) National $\mathrm{CO}_{2}$ Emissions from Fossil-Fuel Burning, Cement Manufacture, and Gas Flaring: 1751-2010. http://cdiac.ornl.gov/ftp/ndp030/nation.1751_2010.ems

[7] Schlesinger, M.E., Ring, M.J. and Cross, E.F. (2012) A Revised Fair Plan to Safeguard Earth's Climate. Journal of Environmental Protection, 3, 1330-1335. http://www.scirp.org/journal/PaperInformation.aspx?paperID=23864 http://dx.doi.org/10.4236/jep.2012.310151

[8] Anonymous (2009) ECO2 80/50 The European Future Project against Climate Change. http://www.euco2.eu/resources/EUCO2-Summary-Newest.pdf

[9] Anonymous (2009) Presidency Conclusions-Brussels, 29/30 October 2009. Council of the European Union, Brussels, $24 \mathrm{p}$.

[10] IPCC (2007) Summary for Policymakers. In: Metz, O.R.D.B., Bosch, P.R., Dave, R. and Meyer, L.A., Eds., Climate Change 2007: Mitigation. Contribution of Working Group III to the Fourth Assessment Report of the Intergovernmental Panel on Climate Change, Cambridge University Press, United Kingdom and New York, NY, USA, 24.

[11] Fisher, B.S., Nakicenovic, N., Alfsen, K., Corfee Morlot, J., de la Chesnaye, F., Hourcade, J.-Ch., Jiang, K., Kainuma, M., La Rovere, E., Matysek, A., Rana, A., Riahi, K., Richels, R., Rose, S., van Vuuren, D. and Warren, R. (2007) Issues Related to Mitigation in the Long Term Context. In: Metz, B., Davidson, O.R., Bosch, P.R., Dave, R. and Meyer, L.A., Eds., Climate Change 2007: Mitigation. Contribution of Working Group III to the Fourth Assessment Report of the Inter-governmental Panel on Climate Change, Cambridge University Press, United Kingdom and New York, NY, USA.

[12] United Nations (1992) United Nations Framework Convention on Climate Change. http://unfccc.int/resource/docs/convkp/conveng.pdf

[13] Schlesinger, M.E., Andronova, N.G., Entwistle, B., Ghanem, A., Ramankutty, N., Wang, W. and Yang, F. (1997) Modeling and Simulation of Climate and Climate Change. In: Castagnoli, G.C. and Provenzale, A., Eds., Past and Present Variability of the Solar-Terrestrial System: Measurement, Data Analysis and Theoretical Models, Proceedings of the International School of Physics “Enrico Fermi” CXXXIII, IOS Press, Amsterdam, 389-429.

[14] Schlesinger, M.E., Ring, M.J. and Cross, E.F. (2012) A Fair Plan to Safeguard Earth’s Climate. Journal of Environmental Protection, 3, 1330-1335. www.scirp.org/journal/PaperInformation.aspx?paperID=23864 http://dx.doi.org/10.4236/jep.2012.310151

[15] Schlesinger, M.E., Lindner, D., Ring, M.J. and Cross, E.F. (2013) A Fair Plan to Safeguard Earth's Climate: 3. Outlook for Global Temperature Change throughout the 21st Century. Journal of Environmental Protection, 4, 653-664. www.scirp.org/journal/Paperinformation.aspx?PaperID=33421 http://dx.doi.org/10.4236/jep.2013.46075

[16] Schlesinger, M., Ring, J., Lindner, D., Cross, E. and Prince, V. (2014) Fair Plan 4: Safeguarding the Climate of "This Island Earth”. Atmospheric and Climate Sciences, 4, 431-436. 
www.scirp.org/journal/PaperInformation.aspx?paperID=24290 http://dx.doi.org/10.4236/acs.2014.43041

[17] CDIAC (2013) Preliminary $\mathrm{CO}_{2}$ Emissions 2012.

http://cdiac.ornl.gov/ftp/trends/co2_emis/Preliminary_CO2_emissions_2012.xlsx

[18] White House (2014) Fact Sheet: US-China Joint Announcement on Climate Change and Clean Energy Cooperation. Office of the Press Secretary, Washington DC.

http://www.whitehouse.gov/the-press-office/2014/11/11/fact-sheet-us-china-joint-announcement-climate-change-and-c lean-energy-c 
Scientific Research Publishing (SCIRP) is one of the largest Open Access journal publishers. It is currently publishing more than 200 open access, online, peer-reviewed journals covering a wide range of academic disciplines. SCIRP serves the worldwide academic communities and contributes to the progress and application of science with its publication.

Other selected journals from SCIRP are listed as below. Submit your manuscript to us via either submit@scirp.org or Online Submission Portal.
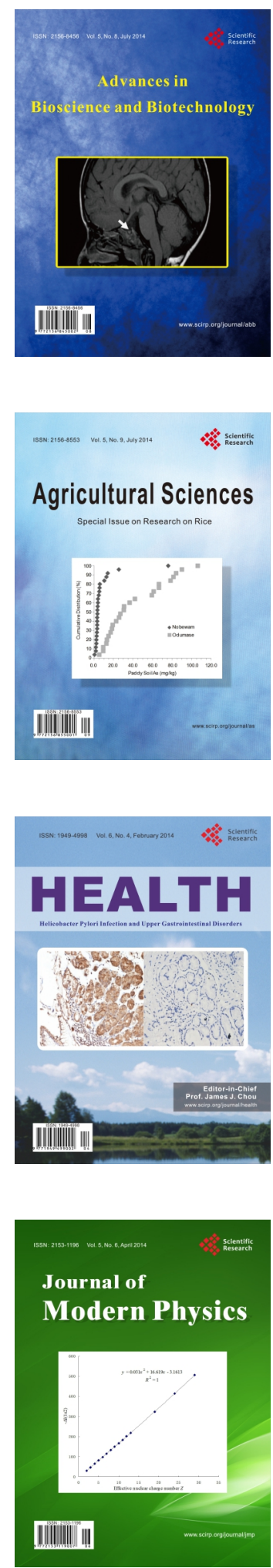
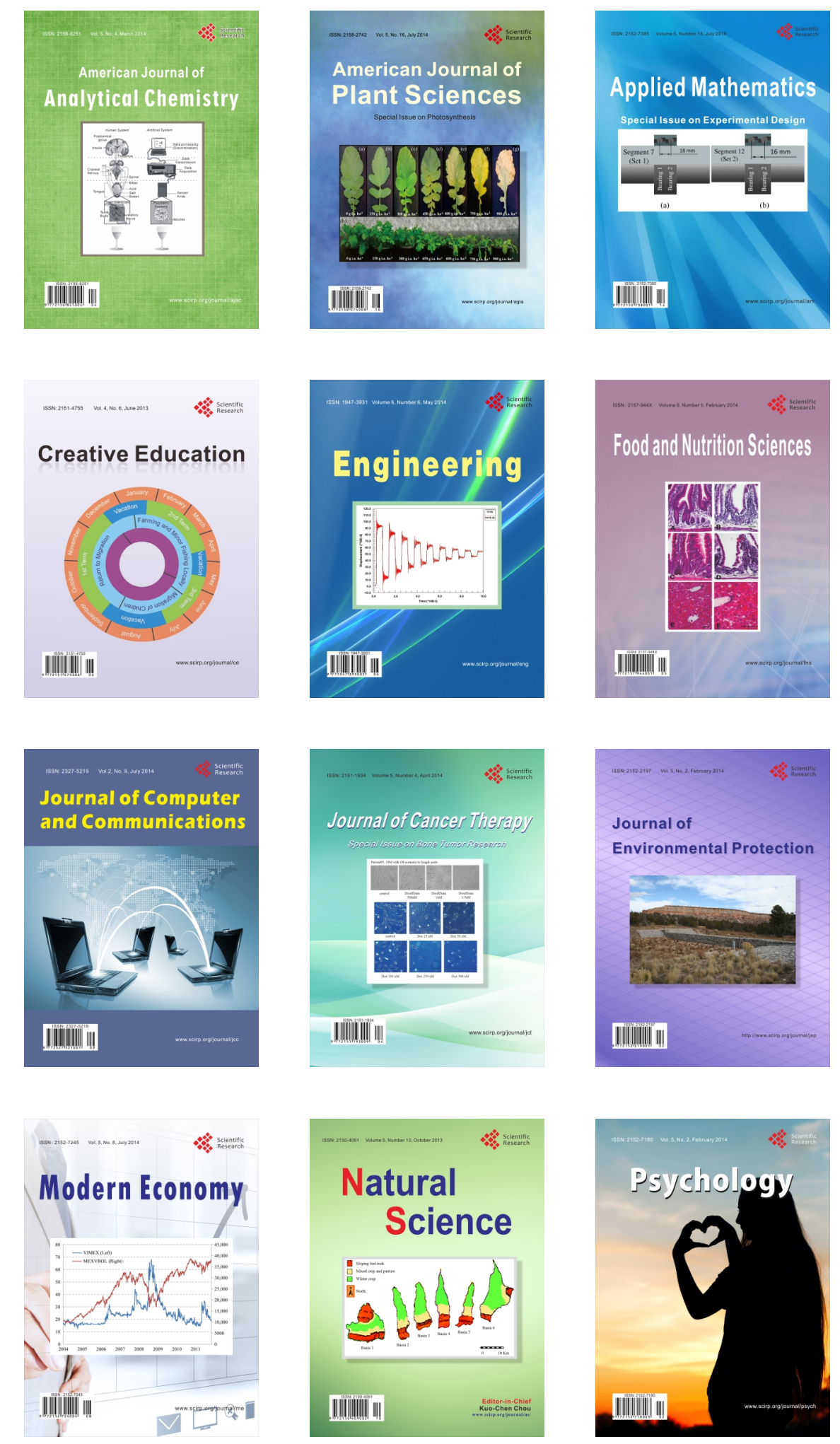